\title{
SISESTATUD TARINDID LEPINGUTE TEKSTIMOODUSTUSVÕTTENA
}

\author{
Riina Reinsalu
}

Ülevaade. Töövõtu- ja käsunduslepingute keeleanalüüs näitab, et lepingute lausestruktuur on võrdlemisi lihtsakoeline: tekst koosneb peamiselt lihtlausetest ja lihtsa ülesehitusega (enamasti esimese astme kõrvallausetega) liitlausetest. Ent ometigi on lepingute keelekasutus raskepärane. Kuna keerukaid lauseskeeme rakendatakse lepingutes harva, püütakse vajaminevat teavet edasi anda mitmesuguste sisestatud tarinditega. Infiniit- ja partitsiiptarindite, nominalisatsioonide, adverbialisatsioonide ja predikaadita tarindite rohkus, kombineerituna kantseliitliku väljendusviisiga, muudab laused kohmakaks ja raskesti mõistetavaks. Teisalt aga täidavad need tarindid tekstimoodustuse seisukohalt lepingutes kindlaid funktsioone, milles peegeldub lepingu kui žanri olemus.

Võtmesõnad: žanr, žanrianalüüs, õiguskeel, eesti keel

\section{Tekstide uurimisest žanrianalüüsi meetodil}

Tekstide käsitlemisel kas igapäeva- ja tööelus või keeleteaduslikus uurimuses ei saa läbi liigitamise ja nimetamiseta. Me eristame ilukirjandus- ja tarbetekste ning tarbetekstide alaliikidena näiteks reklaam-, teadus-, poliitika-, ajakirjandus- ja ametitekste. Meil on ettekujutus sellest, millised keele- ja struktuurivahendid kuuluvad näiteks ametitekstide arsenali, ning teeme seeläbi vahet protokollil ja aruandel, korraldusel ja otsusel, kiituskirjal ja diplomil, volikirjal ja lepingul. Ent žanrianalüüsiks üksnes sellisest kogemustele tuginevast liigitus- ja nimetusviisist ei piisa: vaja on sisu, struktuuri ja keelevahendite, aga ka situatsiooni- ja kultuurikonteksti üksikasjalikku analüüsi.

Žanr liigituskategooriana on funktsionaalses keeleteaduses tugevasti juurdunud, kuid žanri olemust mõistetakse erinevalt. Üldjoontes ollakse üksmeelel selles, et žanr on abstraktne kategooria (vt nt Fairclough 2003). Samuti on levinud seisukoht, et žanr põhineb eesmärgipärasel tegevusel, kuigi puudub ühene arusaam sellest, 
mida see eesmärk endast õigupoolest kujutab. Seetõttu otsivad žanrianalüüsi teoreetikud muu hulgas vastust küsimusele, kas tekstil on ainult üks eesmärk või sisaldab tekst peale üldtunnustatud eesmärgi ka varjatud eesmärke, kas žanri uurimisel tuleks lähtekohaks seada seesama eesmärk (needsamad eesmärgid) või hoopistükkis teksti vormiline külg ning kuidas suhestuvad žanrid kultuurikontekstiga.

Kui 1990-ndate alguse funktsionaalses žanriteoorias juhinduti peamiselt põhimõttest, et žanri tuvastamiseks on vaja uurida teksti (kommunikatiivset) eesmärki (vt nt Swales 1990, Bhatia 1993), siis hiljem on ühe eesmärgi otsingutest loobutud. Ka John Swales on koos Inger Askehavega oma hilisemates žanrikäsitlustes sedastanud, et kuigi on tekste (nt retseptid), mille eesmärki on võrdlemisi lihtne tuvastada, leidub ka tekste, millel on hulk eesmärke. Lisaks võivad teksti eesmärgid ajas muutuda, nt kui varem tutvustati ettevõtete brošüürides eeskätt tooteid, siis praegusajal püütakse brošüüride kaudu ka ettevõtet ennast reklaamida, luua temast arvestatava ja usaldusväärse partneri kuvand, tutvustada töötajatele ettevõtte põhiväärtusi ja tugevdada meeskonnavaimu. Niisamuti ei saa lähtekohaks seada üksnes teksti vormilist külge, sest leidub tekste, millel on küll sama vorm, kuid erinev sisu (eesmärk). Lisaks takistaks selline välistel tunnustel põhinev analüüs alažanrite eristamist, sest teatud tasandil ei tuvastata alažanreid mitte vormiliste, vaid sisuliste tunnuste alusel. (Askehave, Swales 2001: 195-204) Liiatigi leidub tekste, mille puhul on nimme tekitatud sisu ja vormi ebakõla, nt võib armastuskiri olla vormistatud lepinguna või ostunimekirjale mnemotehnilisel eesmärgil antud luuletuse vorm.

Ka kultuuriti võivad žanril olla erinevad eesmärgid. Näiteks selgub müügikirjade võrdlusest, et USA müügikirjad on enamjaolt sihitud lühiajaliste suhete loomisele ning toote või teenuse müümiseks kasutatakse sageli survemeetodit, seevastu Hiinas püütakse müügikirjade abil luua pikaajalisi töösuhteid, avaldamata selleks survet. Surve vältimine on märk harmooniast ja austusest. Lisaks hoidutakse hiinakeelsetes müügikirjades osutamast madalatele hindadele, sest madal hind seostub tihti halva kvaliteediga, mistõttu rõhutatakse erihindu. Kultuurierinevused tulevad esile ka kirjade formaalsuses: Hiina müügikirjad on kirjutatud ametlikus registris (keeleline distants väljendab austust lugeja vastu), kuid USA müügikirjadele on iseloomulik familiaarsem väljenduslaad (Zhu 2000: 52-61).

Niisiis võib žanrit pidada keelekasutusviisiks, mille eesmärk (eesmärgid) ja keelevahendid peegeldavad kultuuritavasid. Tekste žanrianalüüsi meetodil uurides tuleb arvesse võtta nii vormi kui ka sisu ning tõlgendada tulemusi konteksti taustal: vaadata, mis tekstis on ja kuidas see "miski" on esitatud ning miks on seda just sellisel viisil tehtud.

\section{Lepingukeele lausestruktuuride analüüs}

Olen seni käsitlenud lepingute üldstruktuuri: uurinud Otepää vallavalitsusega sõlmitud 39 töövõtu- ja käsunduslepingu ${ }^{1}$ näitel, mis osadest lepingud koosnevad ning kuidas korduvad vormielemendid annavad lepingule just sellise kuju, mille järgi me tavatseme üht või teist teksti lepinguks pidada (vt Reinsalu 2011). Üldstruktuuri analüüsi rikastab lepingute lausestruktuuri analüüs, mis põhineb pind-ja

http://avalik.amphora.ee/otepaa/documents.aspx?org=66\&unit=-1\&fid=272; http://avalik.amphora.ee/otepaa/ documents.aspx?org=66\&unit=-1\&fid=271 (25.01.2009). 
süvastruktuuri lausete eristusel. Selle kohaselt koosnevad kõik pindstruktuuri laused (st laused sellisel kujul, nagu need lepingus esinevad) süvastruktuuri tasandil ühest või mitmest elementaarlausest ehk propositsioonist. Olenevalt sellest, millise kuju on need propositsioonid pindstruktuuris võtnud, võib eristada pea-, kõrvalja kiillauseid, mis on ka vormi poolest laused, ning infiniit- ${ }^{2}$ ja partitsiiptarindeid, nominalisatsioone, adverbialisatsioone ja predikaadita tarindeid ${ }^{3}$, mis kuuluvad sisestatud tarindite hulka. (Meetodi kirjeldust vt Reinsalu 2012, Kasik 2002.)

1405 pindstruktuuri lause (13 305 propositsiooni) analüüs näitab, et lepingukeele keerukuse seisukohalt on pea- ja kõrvallausete osatähtsus võrdlemisi tagasihoidlik: tekst on esitatud peamiselt lihtlausete ja elementaarsete liitlausete kujul, mistõttu puuduvad keerukad hierarhiasuhted pea-ja kõrvallausete vahel. Seevastu kiilud, mis lausetesse pikituna annavad mitmesugust taustteavet, kuid on ülejäänud lausega enamasti grammatiliselt seostamata, raskendavad lepinguteksti lugemist ja mõistmist tunduvalt. Lepingukeele keerukus seisneb aga sisestatud tarindite rohkuses ja funktsioonides.
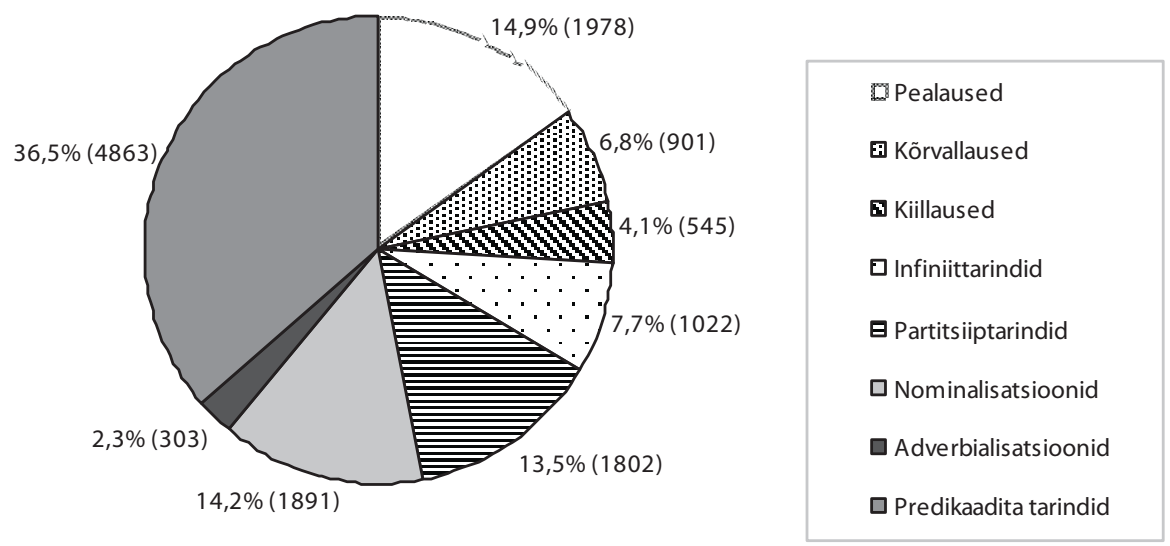

Joonis 1. Analüüsimaterjali jagunemine eri lauselisuse tasandiga tarindite vahel

Jooniselt 1 nähtub, et predikaadita tarindid moodustavad selgelt kõige esindatuma lauselisuse tasandi. Pealaused on küll hulga järgi teisel kohal, kuid neid on predikaadita tarinditest üle poole võrra vähem, lisaks jääb nende hulk samasse suurusjärku partitsiiptarindite ja nominalisatsioonide omaga. Ka kõrvallausetel on lepingusüntaksis täita võrdlemisi marginaalne roll, sest nad edestavad oma hulga poolest vaid kiillauseid ja adverbialisatsioone (seega tasandeid, mis on mistahes tekstides niigi väiksema esindatusega) ning neid on ka infiniittarinditest vähem. Selles artiklis keskendun infiniit- ja partitsiiptarinditele, nominalisatsioonidele, adverbialisatsioonidele ja predikaadita tarinditele.

\section{Infinittarindid}

Infiniittarindeid on vaatlusaluse materjali hulgas 7,7\% (1022 propositsiooni). Tarindiliikide alusel on jaotumus järgmine: supiinitarindid $-51,2 \%$ (524 propositsiooni), infinitiivitarindid - 34,9\% (356 propositsiooni) ja gerundiivitarindid - 13,9\% (142 propositsiooni). Kui supiinitarindid hõlmavad nii ma-infinitiivi kui ka selle

2 Infiniittarinditena käsitlen siin kõiki muid infiniitseid tarindeid peale partitsiiptarindite.

3 Predikaadita tarinditena käsitlen siin substantiivi- ja kvantorifraase, mis süvastruktuuris on enamasti olemaverbiga predikatiiviga lause ja omajalause kujul. 
käändevorme (lepingutes mast- ja mata-vorm), siis infinitiivitarindite koguhulk väljendab üksnes $d a$-infinitiivi hulka, sest vat-vormi lepingutes ei kasutata. Gerundiivitarinditest on lepingutes esindatud vaid des-gerundiiv.

\subsection{Supiinitarindid}

Infiniittarinditest moodustavad üle poole supiinitarindid, millest $85 \%$ esineb mainfinitiivi (444 propositsiooni) ja 15\% selle käändevormide kujul (80 propositsiooni). Vaatlusalused ma-infinitiivid laiendavad üksnes verbe (tabel 1).

Tabel 1. Verbid, mida ma-infinitiiv laiendab

\begin{tabular}{|l|c|}
\hline \multicolumn{1}{|c|}{ Verb } & Arv \\
\hline kohustuma & 286 \\
\hline kohustama & 90 \\
\hline pidama & 62 \\
\hline asuma & 5 \\
\hline volitama & 1 \\
\hline Kokku & 444 \\
\hline
\end{tabular}

Enim tarindeid on moodustatud deontilismodaalsete verbidega kohustuma $(64,4 \%)$ ja kohustama (20,3\%), mille suur esinemus on otseses seoses lepingu põhifunktsiooniga reguleerida lepingupoolte suhteid. Verb kohustuma on suunatud tegijale endale: lepingupool võtab endale kohustuse midagi teha (1). Verb kohustama aga eeldab, et on öeldud, kes kohustas keda mida tegema, kuid lepingutes moodustab kohustama üksnes passiivkonstruktsioone (2).

(1) Töövõtja kohustub Tellijale üle andma KSH programmi eelnõu KSH programmi avalikustamiseks 25. jaanuariks 2009.a.

(2) Tellija on kohustatud andma Töövõtja käsutusse Töö teostamiseks vajalikud vahendid ja informatsiooni.

Kohustuslikkustähendus on ka modaalverbil pidama (13,9\%). Umbes pooltes pidama-tarindites esineb agent individualiseeritult (3), kuid konstruktsiooni pidama + olema + -tud sisaldavates lausetes on agent impersonaalne (4). Ka ajakirjandus- ja ilukirjandustekstide analüüsist ilmneb, et sageli välditakse pidamatarindites agendi nimetamist (Penjam 2008: 181). Tihti kasutatakse modaalverbi pidama ka seisundilausetes, et märkida esemete vms kohustuslikke omadusi (5).

(3) Töövõtja peab Tööde lõpetamisel hankima töö üleandmiseks vajalikud load ja kooskõlastused ning koostama vajaliku täitedokumentatsiooni.

(4) Kõigi ülalmainitud infovahetuste puhul peavad lähetised olema saadetud allpool nimetatud või hiljem määratud teistele täievolilistele esindajatele.

(5) Pooltevahelised käesoleva Lepinguga seotud teated peavad olema kirjalikus vormis, välja arvatud juhtudel, kui sellised teated on informatsioonilise iseloomuga, mille edastamisel teisele poolele ei ole õiguslikke tagajärgi. 
Deontilist modaalsust annab edasi ka verbi volitama ja supiini tarind (6), kuid volitamist kasutatakse lubatuse väljendamise vahendina vaid ühes lauses. Niisamuti leidub vaid üksikuid näiteid alustamist väljendava verbi asuma ja supiini kooskasutuse kohta (7).

(6) Otepää Vallavalitsus volitab advokaat Kalju Kutsarit esindama Otepää Vallavalitsust Tartu Halduskohtus haldusasjas nr 3-08-9 kohtulikul arutamisel kõigi seaduses sätestatud õigustega, välja arvatud õigus kaebus õigeks võtta ja/või sõlmida ilma täiendavate volitusteta kaebuse esitajaga kokkuleppeid asja kohtuväliseks arutamiseks.

(7) Hankija võib teha kirjaliku hoiatuse järgmistel juhtudel:

- pole asutud 48 tunni jooksul alates rikke avastamisest või sellekohase teate saamisest lampide läbipõlemise põhjusi välja selgitama, vigu likvideerima või lampe vahetama

Kohustuste seesugune esitusviis on kooskõlas nii registri (ametlik), valdkonna (lepinguõigus) kui ka kanaliga (kirjalik). Kuna puudub otsene adressaat, ei saa lepingutes rakendada käskivas kõneviisis väljendatud direktiivsust. Samuti pole õigustekstides tavaks kasutada kaudseid kohustamisstrateegiaid (uurida lepingupoole võimalust või soovi midagi teha).

Supiini käändevormidest on vaatlusaluses materjalis kasutatud peamiselt mata-vormi, mis esineb enamasti atribuudi (8) või sõltuvusmääruse (9), harvem seisundimääruse (10) või predikatiivi kujul (11). Verbidega vaatama ja hoolima moodustatud mata-tarindid (12) pakuvad aga näiteid sõnavormide kaassõnastumise kohta ning väljendavad mööndusmäärustena mingeid tingimusi või piiranguid (vt Uuspõld 2001). mast-tarindit esineb tekstis vaid kahel korral, mõlemal juhul koos negatiivimplikatiivse verbiga keelduma (13). Supiini käändevormide vähesust ja liigivaesust võib pidada lepingute erijooneks.

(8) Viivis maksmata summalt on $0,5 \%$ päevas.

(9) Juhul kui TELLIJA jätab projektiplaani ja pakkumised õigeks ajaks esitamata, lükkub TÄITJA esitatava töö tähtaeg viivitatud päevade võrra edasi.

(10) Juhul, kui Tellija ei ole teostatud tööde kvaliteediga rahul või leiab, et töö jäi tegemata, informeerib ta koheselt sellest Töövõtjat (tel nr xxxx xxxx).

(11) Tellijal on õigus nõuda Töövõtjalt viivist null koma viis $(0,5) \%$ tähtajaks esitamata Projekteerimistööde maksumusest iga kalendripäeva eest, kui Projekteerimistööd või projektdokumentatsioon on ettenähtud tähtajaks Tellijale kohaselt üle andmata või koostamata.

(12) Tellija ei täida kirjalikust meeldetuletusest hoolimata käesoleva lepinguga sätestatud maksekohustusi.

(13) Kui Tellija keeldub tööde üleandmis-vastuvõtuaktile alla kirjutamast, kohustub ta selle kirjalikult põhjendama hiljemalt viie kalendripäeva jooksul, vastasel korral loetakse akt allakirjutatuks; 


\subsection{Infinitiivitarindid}

Teise suure infiniittarindite rühma moodustavad 34,9\%-ga infinitiivitarindid (356 propositsiooni), mis paistavad silma oma süntaktilise kasutusvaldkonna üheülbalisusega: 94\% analüüsitud $d a$-infinitiividest (333 propositsiooni) talitleb laiendina ja 4,5\% (17 propositsiooni) otstarvet väljendava kõrvallause predikaatverbina, ülejäänud 1,5\% (6 propositsiooni) täidab mingit muud funktsiooni (perifrastilise verbi koosseisus, käsklause predikaadina).

Kui $m a$-infinitiivid moodustavad tarindeid vaid verbidega, siis $d a$-infinitiivid laiendavad nii substantiive (57\%) kui ka verbe (37\%), kuid ka siin avaldub sama seaduspära mis ma-infinitiivi puhul: välja on kujunenud kindlad sõnad, mille laiendina infinitiiv talitleb.

Tabel 2. Substantiivid, mida da-infinitiiv laiendab

\begin{tabular}{|l|c|}
\hline \multicolumn{1}{|c|}{ Substantiiv } & Arv \\
\hline õigus & 190 \\
\hline kohustus & 6 \\
\hline tahe & 3 \\
\hline alus & 2 \\
\hline volitus & 1 \\
\hline valmisolek & 1 \\
\hline Kokku & 203 \\
\hline
\end{tabular}

Tabel 3. Verbid, mida da-infinitiiv laiendab

\begin{tabular}{|l|c|}
\hline \multicolumn{1}{|c|}{ Verb } & Arv \\
\hline võima & 77 \\
\hline tulema & 15 \\
\hline õnnestuma & 10 \\
\hline saama & 6 \\
\hline suutma & 5 \\
\hline tohtima & 5 \\
\hline võimaldama & 4 \\
\hline soovima & 2 \\
\hline vajalik olema & 2 \\
\hline võimalik olema & 2 \\
\hline aitama & 1 \\
\hline püüdma & 1 \\
\hline Kokku & 130 \\
\hline
\end{tabular}

Tabelist 2 nähtub, et substantiivide hulgas domineerib 94\%-ga selgelt sõna õigus, mis väljendab lubatust sooritada infinitiiviga tähistatud tegevust, ülejäänud $6 \%$ moodustavad sõnad kohustus, tahe, alus, volitus ja valmisolek. Tarindi koosseisus esinevate verbide rida on märksa pikem, kuid ka siin on kujunenud välja selge vastandus: modaalverb võima (59\%) vs. muud verbid (41\%) (tabel 3). 
Suurima rühma moodustavad $d a$-infinitiivi tarindites sõnad, mis esindavad deontilist modaalsust: lubatust väljendab sõna õigus, kuid ka võima, tohtima ja volitus ning kohuslikkust sõnad tulema ja kohustus.

Enamasti fikseeritakse substantiivi õigus ja $d a$-infinitiivi tarindiga lepingupoolte eriõigused (14), harvem väljendatakse sellega mõlema lepingupoole ühisõigusi (15). Eitust kasutatakse substantiivi õigus ja da-infinitiivi tarindis harva (16), mis osutab sellele, et keelatust tähistatakse lepingutes muude vahenditega.

(14) Töövõtjal on õigus alustada tootmist kohe peale käesoleva lepingu allakirjutamist.

(15) Pooltel on õigus mõlemapoolsel kokkuleppel Leping lõpetada mistahes staadiumis.

(16) Töövõtjal ja Tellijal ei ole õigust anda kolmandatele isikutele informatsiooni Lepingu sõlmimise käigus teatavaks saanud asjaolude kohta, välja arvatud seaduses sätestatud juhtudel.

Loatähendus on ka 60\%-l võima-tarinditest, mis esinevad peamiselt agendiga tegevusprotsesse väljendavates pealausetes (17), harvem impersonaalse agendiga lausetes, kus agendi saab konteksti või lause põhjal hõlpsalt tuvastada. Näiteks pole lauses 18 öeldud, kes teadet edastab, kuid varasemate lepingupunktide ja üldise konteksti põhjal võib aimata, et teate edastaja on emb-kumb lepingupool. Deontilist tähendust kannab võima ka oleviku eitavas kõnes (19).

(17) Tellija võib nõuda ebakvaliteetselt tehtud töö tasuta ümber tegemist.

(18) Informatsioonilist teadet võib edastada ka suuliselt ja telefoni kaudu.

(19) Lepingu tõlgendamise aluseks ei või olla ebaõige tähistus ega väljendusviis, mida Pooled kasutasid eksimuse tõttu.

Peale võima moodustab da-infinitiiviga ahelverbe modaalverb tohtima, mis on lepingutes üksnes eitavas kõnes (20). Ka $d a$-infinitiivi tarindite analüüs ajakirjandus- ja ilukirjanduskeele põhjal kinnitab modaalverbi tohtima eituslembust võrreldes teiste modaalkonstruktsioonidega (Penjam 2008: 135).

(20) Täitja ei tohi käesolevast Lepingust tulenevaid õigusi ja kohustusi üle anda kolmandatele isikutele ilma Tellija kirjaliku nõusolekuta.

Tegevuse sooritamiseks antakse agendile luba ka substantiiviga volitus, kuid seda vaid ühel korral (21). Kuna volitama-tarindeid on samuti vaid üks, viitab see sellele, et volitama tegevusena pole lepingutele iseloomulik (õiguste andmist ei nimetata volitamiseks).

(21) Lepingujärgne Töövõtja esindaja on P. K., Corrente Grupp OÜ projektijuht (tel nr xxxxxxx), kellel on volitus kirjutada alla Tehtud tööde aktile

Tegevuse kohustuslikkus on $d a$-infinitiivi ühendites vormistatud peamiselt verbi tulema abil. Kõikidel juhtudel on agent jäetud nimetamata: see, kellele kohustus on suunatud, selgub eelnevatest ja järgnevatest lepingupunktidest. Verb tulema on da-infinitiivi tarindites alati jaatavas kõnes (22). Selline kasutus pole lepinguspetsiifiline, sest samalaadseid tulemusi on andnud ka muude tekstide analüüs (vt nt Mandra 2007: 28, 39). 
(22) Töö peatumise nõue tuleb Töövõtjale teatada kirjalikult.

$d a$-infinitiivi tarindeid substantiiviga kohustus esineb vaatlusaluses materjalis kuus korda (23). Sellist väikest esinemust võib põhjendada sellega, et kohustuslikku tegevust ei märgita mitte substantiivi ja $d a$-infinitiivi ühendi, vaid verbide kohustama ja kohustuma ning ma-infinitiivi abil või on kasutatud selleks mõnda muud kohustavat verbi (nt pidama).

(23) Lepingu ennetähtaegsest lõpetamisest on lepingupooltel kohustus teatada teisele osapoolele vähemalt kolm kuud ette.

Deontilise modaalsuse väljendusvahendite hulka kuuluvad ka mõned $d a$-infinitiivi ja verbiühendi vajalik olema tarindid (24).

(24) Nimetatud tingimus ei laiene informatsioonile, mis on avalikkusele kättesaadav ning mida on vajalik avaldada Töö teostamiseks.

Teine osa infinitiivitarinditest väljendab dünaamilist võimalikkust ehk agendi võimelisust sooritada tegevus. Võimalikkustähendus on $d a$-infinitiivi ühenditel verbidega õnnestuma ja suutma, modaalverbidega saama ja võima ning ühendiga võimalik olema.

Verbi õnnestuma ja da-infinitiivi tarindid esinevad üksnes (juhul) kui tingimuslausetes, seejuures on verb eitavas kõnes, väljendades tegevusi, mida pole võimalik teha (25). Viide agendile puudub, kuid võttes arvesse, et kõik $d a$-infinitiiviga edasi antavad tegevused (vaidluste lahendamine, kokkuleppe sõlmimine, ühise tahte kindlakstegemine) nõuavad kaht osalist, siis on impersonaalseks agendiks nii teenuse tellija kui ka täitja. Sama moodi on üksnes eitavas kõnes ka verb suutma, mis kätkeb endas võimetust sooritada $d a$-infinitiiviga märgitud tegevust (26). Verbi suutma sisaldavates tarindites on agent isikustatud, olles väljendatud kas kokkulepitud nimetuse või isikulise asesõnaga.

(25) Juhul, kui lahkhelisid ei ónnestu lahendada eelnimetatud korras, lahendatakse vaidlus kohtus.

(26) Garantiiperioodi jooksul kohustub töövõtja kõrvaldama omal kulul kõik defektid ja tegematajätmised, kui ta ei suuda tõestada, et seda on kohustatud tegema keegi kolmas.

Kuigi modaalverbi saama abil on võimalik väljendada nii võimalikkust, tõenäosust kui ka kohustuslikkust, on saama lepingutes üksnes võimalikkuse väljendamise teenistuses ja sedagi harva (27). Niisamuti leidub vaid paar näidet ühendit võimalik olema sisaldavate tarindite kohta (28). $d a$-infinitiiviga väljendatud tegevuse võimalikkust annab edasi ka modaalverb võima, mis on kasutusel peamiselt kõrvallausetes, kus see on tavaliselt isikulises tegumoes ja jaatavas kõnes (29).

(27) Kui Töövõtja teade Tellijale on otstarbekohasel viisil edastatud (fax, e-mail, kiri), saab Töövõtja tugineda teatele, hoolimata selle hilinemisest, moondumisest või mitte kohale jõudmisest.

(28) Juhul kui üleskerkinud küsimust või probleemi ei ole põhjendatult või Tellijast olenematutel asjaoludel võimalik ülalmärgitud tähtaja jooksul lahendada, teatab Tellija sellest koheselt Käsundisaajale. 
(29) Lepingupool kohustub teist Poolt informeerima kõikidest olulistest asjaoludest, mis võivad mõjutada või takistada käesolevas Lepingus sätestatud kohustuste täitmist või õiguste realiseerimist.

Võimalikkustähendusele on lähedane võimaldamistähendus, mida väljendavad da-infinitiivide tarindid verbidega võimaldama (30) ja aitama (31). Võimalust väljendatakse üksikjuhtudel ka substantiividega alus ja valmisolek: esimene neist viitab välisele ressursile midagi teha (32), teine sisemisele (33).

(30) (Tellija) tagab et Töövõtjale Ehitus- ja hooldustööde tegemiseks üleantavad pinnad on seisundis, milline võimaldab Töövõtjal alustada Ehitus- ja hooldustööde tegemist või nende korraldamist lepingus sätestatud tingimustel ja korras

(31) Esitama Töövõtjale lisaks käesoleva lepingu dokumentides nimetatud lähteandmetele viivitamatult projekteerimistööde teostamiseks vajalikud täiendavad lähteandmed mis aitavad kiirendada käesoleva lepingu täitmist.

(32) Kui Tellijal on Töövõtja ees võlgnevusi käesoleva Lepingu alusel või muude Green Building Development OÜ ja Otepää Vallavalitsuse vahel sõlmitud lepingute alusel või kui Töövõtjal on pärast käesoleva Lepingu sõlmimist teatavaks saanud sellised asjaolud, mis annavad piisavalt alust arvata, et Tellija ei suuda Projekteerimistööde eest tasuda maksejõuetuse tõttu, on Töövõtjal õigus mitte anda valmis Projekteerimistöid üle enne kui Tellija on likvideerinud oma võlgnevused Green Building Development OÜ ees või tasunud Projekteerimistööde eest ette.

(33) Pooled deklareerivad oma tahet ja valmisolekut suunata parimad jõupingutused Lepingust tulenevate kohustuste täitmisele, austades ja järgides teise poole seaduslikke ja Lepingust tulenevaid õigusi ja huve.

Agendi sisemine tahe avaldub ka soovimiskonstruktsioonide kaudu. $d a$-infinitiiviga edasiantava tegevuse soovimist märgivad soovima (34), püüdma (35) ja tahe (33). Nende kohta leidub vaatlusaluses materjalis vaid üksikuid näiteid, seega väljendatakse lepingupoolte subjektiivseid tahteavaldusi $d a$-infinitiivi abil harva.

(34) Kui Tellija soovib Lepingu tähtaega lühendada, teeb ta vastava ettepaneku kirjalikult Töövõtjale.

(35) Lepingust tulenevad vaidlused püütakse lahendada Poolte läbirääkimistel.

Peale selle, et $d a$-infinitiiv moodustab tarindeid substantiivide ja verbidega, talitleb väike osa (4,5\%) $d a$-infinitiividest otstarvet väljendava kõrvallause predikaatverbina (36). 1,5\% analüüsitud $d a$-infinitiividest esineb perifrastilise verbi koosseisus (37), samuti on $d a$-infinitiiv kasutusel käsklause predikaadina (38), $d a$-infinitiivitarind alusena (39).

(36) Teenus on käesolevas lepingus kirjeldatud kohustused, mida ehitusjärelvalve litsentsi omav isik täidab Tellija ülesandel, et tagada rekonstrueeritava ehitise vastavus ehitusprojekti dokumentidele, kehtivatele nõuetele ning heale ehitustavale. 
(37) Tellija annab objekti töövõtjale tööde teostamiseks üle pooltele teadaolevas seisundis, töö tegemise koht ja tingimused on töövõtjale eelnevalt teada.

(38) Kokku tasuda summas 86 140.- (kaheksakümmend kuus tuhat ükssada nelikümmend).

(39) Lepingu eesmärgiks on reguleerida Poolte vahel Lepingu alusel ja sellega seoses tekkivaid õigussuhteid.

\subsection{Gerundiivitarindid}

Peale ma- ja da-tegevusnime kuulub infiniittarindite hulka des-gerundiiv, mis on vaatlusaluses materjalis esindatud 13,9\%-ga (142 propositsiooni). 65\% gerundiividest (92 propositsiooni) on moodustatud verbidega arvama, lähtuma, võrdlema, arvesse võtma, arvestama ja algama (40) ning neid tuleks käsitleda kaassõnastunud vormidena (vt nt Uuspõld 2001). Ülejäänud 35\% des-gerundiivi tarinditest (50 propositsiooni) on juhuslikumat laadi, andes edasi põhilause sündmusega samaaegset tegevust (41). Gerundiivide süntaktiline funktsioon on väljendada mingeid tingimusi.

(40) Eelpool nimetatud asjaoludest peab Töövõtja Tellijat kirjalikult informeerima viie (5) päeva jooksul alates asjaolude ilmnemisest.

(41) Pooled võivad omavahelisel kokkuleppel lepingutingimusi muuta, vormistades need vastavalt kehtivale korrale.

Tarindid, mille koosseisu kuuluvad kaassõnastunud gerundiivivormid alates, arvates, lähtudes ja arvestades, on suure esinemissagedusega, ülejäänute esinemus on väiksem. Ka selliste grammatiseerunud vormide nagu arvesse võttes ja võrreldes kohta leidub vaid üksikuid näiteid. Verbi arvesse võtma asemel kasutatakse sagedamini samatähenduslikku verbi arvestama, kuid sõna võrdlema väikest esinemust võib seletada lepingu üldise laadiga: lepingutele pole komparatiivi jm grammatiliste ja leksikaalsete võrdlusvahendite kasutamine omane.

\section{Partitsiiptarindid}

Partitsiiptarindid on vaatlusaluses materjalis esindatud 13,5\%-ga (1802 propositsiooni). Nagu infiniittarindid ja nominalisatsioonid, nii ka partitsiiptarindid annavad edasi mitmesugust tegevust, muutes sündmuste edastamise mitmekihilisemaks. Lisaks täidavad partitsiiptarindid lepingutes eriülesandeid: kehtestavad piiranguid (nt teostatud töö, kokkulepitud hind), esitavad tekstisiseseid viiteid (nt käesolev leping, antud olukord) ja väljendavad kohustuslikkust (nt tasumisele kuuluv summa).

Lepingutes talitlevad partitsiiptarindid peamiselt atribuudina: 96\% neist (1730 propositsiooni) väljendab substantiivist põhjaga tähistatud isiku, eseme, nähtuse vms mõnd tunnust. 1,6\%-l partitsiiptarinditest (29 propositsiooni) on öeldistäite funktsioon (42). 2,3\% (41 propositsiooni) esineb lauses lokatiivse (43) või latiivse seisundimääruse (44) või sõltuvusmääruse kujul (45), seejuures moodustab 
alljärgnev ligi kolmandiku muus kui atribuudi positsioonis paiknevatest partitsiipidest, kuuludes 27 lepingu avalõiku. $0,1 \%$ partitsiipidest ( 2 propositsiooni) on sihitise koosseisus (46).

(42) Käesoleva Lepingu täiendused ja muudatused on kehtivad ainult juhul, kui nad on koostatud kirjalikus vormis ning allkirjastatud mõlema Osapoole poolt.

(43) Käsundisaaja kohustub hoidma tsiviilvastutuskindlustus kehtivana kogu käesoleva Lepingu kehtivuse perioodi jooksul.

(44) Lepingu tingimuste tõlgendamisel eelistatakse tõlgendust, mis muudab Lepingu tingimuse seaduslikuks või kehtivaks.

(45) Otepää Vallavalitsus, (edaspidi nimetatud Tellija), keda esindab ja OÜ Vivocard Plus, (edaspidi nimetatud Töövõtja), keda esindab juhatuse liige A. K., sõlmisid käesoleva lepingu alljärgnevas:

(46) Kui viivitused on tingitud Tellijast mitteolenevatel põhjustel, kohustub Töövõtja tegema kõik endast sõltuva selle takistuse kõrvaldamiseks.

Nagu partitsiiptarindite liigilisest jaotumusest ilmneb, on lepingutes kõige arvukamalt esindatud atributiivsed partitsiiptarindid. Nende hulgas on ülekaalus tud(48\%) ja $v$-partitsiibid (42,5\%), tav- ja nud-partitsiipe on vähem (vastavalt $6,3 \%$ ja $3,2 \%)$. Partitsiibi kujul esitatud verbide loetelu on esinduslik, sageduse alusel võib tuua välja verbid teostama (nt teostatud projekteerimistööd), tegema (nt tehtud tööd), esitama (nt esitatud aktid) ja nimetama (nt eelnimetatud summa). Kahetine roll on verbil kuuluma: tavaliselt väljendatakse sellega füüsilist kuuluvussuhet (47), kuid lepingutes on see kasutusel pigem ülekantud tähenduses - midagi tuleb millegagi teha (48). Sellist väljendusviisi peetakse kantseliitlikuks. Niisamuti väljendab kaudset kuuluvussuhet verbist omama moodustatud $v$-partitsiip lepingutele omases lõpulauses (49).

(47) Käesoleva Lepingu esemeks on Otepää vallale kuuluva Lipuväljak 13 haldushoone, avaliku WC ja külastuskeskuse (edaspidi - Objekt) hooldustööde teostamine perioodil 01.01.2008-31.12.2008 (edaspidi - Töö) vastavalt käesolevas Lepingus toodud tingimustele.

(48) Kui käesolev Leping lõpetatakse enne täiskuu möödumist, arvutatakse tasumisele kuuluv summa ümber prortsionaalselt tegelikult hooldatud ajale.

(49) Leping on koostatud eesti keeles kahes võrdset juriidilist jõudu omavas eksemplaris, millest kummalegi poolele jääb üks eksemplar.

Eraldi partitsiibirühma kuuluvad leksikaliseerunud partitsiibid. Need on oma lähteverbist eemaldunud nii tähenduslikult (nad saavad tähenduse üksnes kindlat tüüpi tarindites) kui ka süntaktiliselt (nad ei seo endaga verbi rektsioonilisi laiendeid) (Kasik 2008: 52). Lepingute tüüpnäiteks on partitsiip käesolev, mis esineb tavaliselt koos substantiiviga leping, muude substantiivide kohta leidub vaid üksikuid näiteid (käesolev tehing, käesolev punkt, käesolev säte). See, et käesolev moodustab umbes $15 \%$ kõikidest atributiivsetest partitsiipidest, näitab selgelt 
lepingu koostaja soovi määrata või täpsustada, millest on juttu, lisaks võimendab seda soovi mõne substantiivi tarbetu esisuurtähestamine (50). Reili Argus osutab, et partitsiip käesolev, aga ka näiteks antud, nimetatud, alljärgnev ja vastav talitlevad eesti kirjakeeles määrava artiklina. Nende vohamist soosib traditsioon, lisaks kasutatakse lepingute jm dokumentide koostamisel olemasolevaid vorme, mis kinnistavad sõnastusstampe. (Argus 2005)

(50) Ühe Poole poolt käesoleva sätte rikkumisel käsitletakse teise Poole saadetud teadet käesolevas Lepingus fikseeritud aadressile või faksile kohasel viisil saadetud teatena.

Partitsiipidega seonduvad ka poolt-tarindid. Võrdlus pea- ja kõrvallausete ning nominalisatsioonidega näitab, et just partitsiiptarindid on kõige altimad poolttarindeid moodustama: 61\% poolt-tarinditest on seotud partitsiipidega (51), 31\% nominalisatsioonidega (52) ning 8\% pea- ja kõrvallausetega (53). Agendi paigutamine poolt-tarindisse on tingitud vajadusest väljendada subjekti ja objekti korraga.

(51) Maksmine toimub Tellija poolt kinnitatud Tehtud tööde akti alusel koostatud arve järgi 20 tööpäeva jooksul.

(52) Leping kuulub täitmisele Poolte õigusjärglaste poolt samadel tingimustel.

(53) Käesolevat Lepingut võib muuta või täiendada ainult Poolte kirjalikul kokkuleppel, mis allkirjastatakse Poolte või Poolte valitud esindajate poolt.

\section{Nominalisatsioonid}

Pindstruktuuris on vormitud nominalisatsioonideks 14,2\% süvastruktuuri elementaarlausetest (1891 propositsiooni), mille koguhulk on predikaadita tarindite ja pealausete järel suuruselt kolmas. Umbes $85 \%$ analüüsitavatest nominalisatsioonidest (1607 propositsiooni) on mine-tuletiste kujul, teiste liidetega tuletised moodustavad heterogeense rühma (284 propositsiooni). Süntaktiline funktsioon on neil aga üks: väljendada nimisõnatarindi abil tegevust (midagi muudetakse, täidetakse, tehakse, kasutatakse, korraldatakse jne).

Nominalisatsioonid on lepingute raskesti mõistetavuse üks põhjuseid. Kuna nende hulk jääb alla vaid predikaadita tarindite ja pealausete omale, kinnitab see nominalisatsioonide osatähtsust muude, vähem esindatud lauselisuse tasanditega võrreldes. Seejuures ei piirduta sageli vaid ühe nominaliseeritud protsessi siirdamisega lausesse, vaid laused võivad sisaldada mitut nominaalfraasi (54). Lisaks on nominaalfraasid suhteliselt pikad (55).

(54) Kooskõlastamine käesoleva Lepingu mõistes tähendab Tellijalt kirjalikku taasesitamist võimaldavas vormis nõusoleku saamist.

(55) Käsundisaajal on õigus nõuda ehitusettevõtjalt kasutatud ehitustoodete ja paigaldatud seadmete vastavusdeklaratsioonide ja/ või -sertifikaatide (tunnistuste) ja muude vajalike dokumentide, nagu näiteks garantiikirjad, hooldus- või kasutusjuhendid, originaalide või koopiate esitamist. 
Nominaliseeritud protsessidega seoses pakub ka huvi, kas ja kuidas on agent tekstis väljendatud. Üht võimalust selleks pakub genitiivatribuut (56), kuid enamasti on genitiivatribuudiks siiski lähtelause objekt (57). Sellist tendentsi võib seletada transitiivsete verbide suure esinemusega, sest nende puhul on just objektiline genitiivtäiend keeleomane (Kasik 2006: 30). Näitelauses 56 on nominaliseeritud verb alla kirjutama küll sihiline, kuid kuna objekt (leping) on tõstetud pealause subjekti positsioonile, võimaldab see nominaalfraasi koosseisus esitada ka lähtelause subjekti. Kui selline vangerdus ei ole võimalik, ja enamasti see ei ole, seotakse agent nominaalfraasiga sõna poolt abil.

(56) Leping jõustub mõlema osapoole allakirjutamise päevast.

（57） Leping loetakse lõpetatuks pärast tööde vastuvõtuakti allkirjastamist Tellija ja Töövõtja poolt.

Subjektilise genitiivtäiendi ja sõna poolt tarindis on nominaliseeritud protsessi agent protsessiga grammatiliselt seotud, kuid agent võib paikneda ka mujal lauses. Seda nimetatakse agendi taustalejätuks (Kasik 2006: 30). Agent võib sel juhul olla põhilause subjekti positsioonil (58), kuid nominaalfraas võib paikneda ka kõrvallauses, nominaliseeritud tegevuse agent aga pealauses ja vastupidi (59). Lisaks võib agent olla põhilauses ka muus kui subjekti vormis, nt ablatiivis habitiivadverbiaalina (54).

(58) Lepingujärgsete kohustuste täitmisel juhinduvad Pooled alljärgnevatest Lepingu dokumentidest.

（59） Töövõtjal on õigus katkestada Leping ennetähtaegselt, kui Töö lõpetamine on võimatu Tellija süül.

Agent võib olla tekstist ka taandatud. Taandatuse korral lause agenti ei sisalda, kuid kuna lepingutes on agendiks tavaliselt emb-kumb lepingupool või mõlemad korraga, saab konteksti põhjal agendi hõlpsalt tuvastada. Näiteks pole lauses (6o) öeldud, kes alla kirjutavad, aga keegi teine peale lepingupoolte (või nende esindajate) seda teha ei saa, mistõttu puudub vajadus agenti eraldi nimetada. Niisamuti ilmneb kontekstist, kes peab töid tegema: kuna tellija ülesanne on maksta tasu ja töövõtja ülesanne on teha tööd, on tööde nõuetekohase tegemise kohustus just töövõtjal.

(60) Käesolev Leping jõustub allakirjutamise momendist ja kehtib kuni tööde nõuetekohase teostamiseni.

\section{Adverbialisatsioonid}

Adverbialisatsioonid on 2,3\%-ga (303 propositsiooni) kõige tagasihoidlikumalt esindatud lauselisuse tasand. $l t$-adverbidena väljendavad need tegevuse tingimusi. Umbes 90\% neist on tuletatud adjektiividest, mille hulgas domineerivad ne- (nt pahauskselt, visuaalselt, otseselt) ja lik-liitega adjektiivid (nt tegelikult, ametlikult, tähelepanelikult), kuid adverbe on tuletatud ka line- (nt süüliselt, elektrooniliselt, faktiliselt) ja tu-liitelistest adjektiividest (nt viivitamatult, erapooletult, tähtajatult), üksikuid näiteid on kas-adjektiivide kohta (nt hoolikalt).

Adjektiividest tuletatud adverbide puhul väärib esiletõstmist kaks asjaolu. Esiteks, ligi neljandiku (27\%) nende koguhulgast moodustab adverb kirjalikult. 
Selle sagedast esinemust võib põhjendada lepingupoolte sooviga tagada, et kõik see, milles lepitakse kokku (nt lepingu muudatused, tingimuste kooskõlastused) ja/või mis võiks lepingu täitmist mõjutada (nt probleemid, pretensioonid), oleks kindluse ja ühese arusaadavuse tagamiseks vormistatud paberil. Teiseks, nagu ametitekstide puhul on tavaks kujunenud, leidub ka lepingutes võrdlemisi palju ajamääruslikest sõnaühenditest saadud adjektiivide edasituletisi (nt igapäevaselt, igakordselt, õigeaegselt), samuti selliseid adverbe, mis on tuletatud substantiivi- ja abisõnatüve liitmisel saadud adjektiividest (nt ennetähtaegselt). Selline sõnakasutus on kantseliitlik ning soovitatav on eelistada sõnaühendeid (nt iga päev, iga kord, õigel ajal, enne tähtaja lõppu).

Teise rühma (10\%) moodustavad partitsiipidest tuletatud adverbid. Enamasti on tuletusaluseks $v$-partitsiip (nt püsivalt, piisavalt, eelnevalt), harvem on adverbe tuletatud tud-partitsiipidest (nt põhjendatult, motiveeritult). Adverbe saab moodustada ka tuletamata adjektiividest, mille näiteks on adverb selgelt, kuid selline moodustusviis on lepingutele ebatüüpiline.

Nagu ka eeltoodud näidetest nähtub, on adverbialisatsioonide hulgas ülekaalus ühesõnalised tarindid, laienditega adverbe leidub vaatlusaluses materjalis alla $5 \%$ (61). Ühesõnalisus on üks tunnusjooni, mis eristab adverbialisatsioone teistest sisestustest.

(61) Tellija annab Järelvalvele kõik Ehitusprojekti Dokumente puudutavad muudatused, täiendused ja kokkulepped üle samaaegselt nende üleandmisega Ehitajale.

\section{Predikaadita tarindid}

Predikaadita tarindid moodustavad 36,5\%-ga (4863 propositsiooni) vaatlusaluste lepingute suurima sisestatud tarindite hulga. Kui eeltoodud lauselisuse tasandite puhul ilmnesid sageli selged liigilised erijooned, nt partitsiiptarindite hulgas domineerivad atributiivsed partitsiibid ja nominalisatsioonide hulgas mine-tuletised, siis predikaadita tarindite liigiline pilt on kirjum: leidub genitiiv-, adjektiiv- ja adverbiaalatribuute ning apositsioone sisaldavaid substantiivifraase ja kvantorifraase.

Lepingutele omased predikaadita tarindid on substantiivifraasid, mis sisaldavad genitiiv- ja adjektiivatribuute. Kuna subjektiline (nt poolte valmisolek, tellija nõudmine) ja objektiline genitiivatribuut (nt hooldustöö teostamine, akti allakirjutamine) talitlevad tegevust väljendava põhja laiendina, olen neid käsitlenud nominalisatsioonide koosseisus. Predikaadita tarinditeks liigituvates konstruktsioonides esinevad genitiivatribuutidena peaasjalikult adverbiaalsed genitiivatribuudid (nt töövõtja honorar, inseneri töötund, töövõtja kogemused, valla katlamaja). Adjektiivatribuutide hulgas moodustavad suurima rühma adjektiivid, mis žanrile kohaselt paiknevad põhja suhtes neutraalses eesasendis (nt vahetu teostaja, lepingulised kohustused, õigeaegsed pretensioonid, materiaalne kahju), kuid ka pronoomenitest adjektiivatribuudid on arvestataval hulgal ja liigirikkalt esindatud (nt mõlemad osapooled, mis tahes asjaolu, selline olukord, muu normatïvakt, oma otsus). Muude adjektiivatribuutide, st substantiivi käändevormide (nt sularahata arveldamine, kvalifikatsiooniga tööjõud), adverbide (nt valmis töö, eraldi arve) ja järgarvsõnade (nt esimene osamakse, kolmas isik) kohta leidub näiteid vähem. 
Predikaadita tarindite hulka kuuluvad ka järgarvudega ühendid (nt 11. jaanuar, 2008. aasta).

Peale genitiiv- ja adjektiivatribuutide laiendavad substantiive ka adverbiaalatribuudid, mille esindatus lepingutes on ootuspäraselt väike. Näidetena võib tuua sellised adverbiaalatribuute sisaldavad substantiivifraasid nagu vïvis päevas, muudatused lepingus, mõju lepingu hinnale ja tähtajale.

Lisandit sisaldavate fraaside tüüpiline kasutusvaldkond on tähistada nimeliselt üksikisikuid, kes tuuakse välja esindajate ja kontaktisikutena. Fraasid on lühikesed, tavaliselt on piirdutud üksnes ametinimetustega, nt vallavanem A. P., juhatuse esimees A. M., advokaat $K$. $K$. Ametinimetused on harilikult esitatud eeslisandina, kuid kontaktisikute jaotises on need paigutatud ka järellisandi kohale - nii on fookus isiku nimel (62). Harvem on nimeliselt väljendatud isiku tähistamiseks kasutatud nimetust esindaja, mis viitab lepingust tulenevale isiku funktsioonile, ettevõtlusvormi tähistavat nimetust füüsilisest isikust ettevõtja vm. Muid kui isikuid laiendavate lisandite esinemisjuhud on juhuslikumat laadi. Nii näiteks kuuluvad lisandite hulka ka ettevõtlusvormi tähistavad lühendid ( $A S, M T \ddot{U}$, Ö̈, FIE), mis paiknevad nime ees või järel.

(62) Tellijat esindab Lepingust tulenevates ja sellega seotud õigustes ja kohustustes: K. R., abivallavanem tel xxxx xxxx

Kuna lepingutes fikseeritakse ka makstavad summad, makse- jm tähtajad, moodustavad ühe arvestatava predikaadita tarindite rühma kvantorifraasid. Kvantoriks on põhiarvsõnad (nt kolm kalendripäeva, kakskümmend kaheksa tuhat kaheksakümmend neli krooni), seejuures on sageli arvsõnale vastav arv märgitud arvsõna järele sulgudesse ja vastupidi. Kvantiteedisubstantiivide ja -adverbide puudumine ning põhiarvsõnade domineerimine lepingutes osutavad vajadusele väljenduda võimalikult täpselt, ühtlasi annab selline jaotumus edasi ka tekstiliigilist eripära.

Nagu öeldud, puudub predikaadita tarindite seas mingi tarindiliigi märkimisväärne ülekaal, kuid predikaadita tarindite osatähtsus seisneb nende rohkuses. Genitiiv- ja atribuuttarindid kombineerituna partitsiipide ning subjekt- ja objektatribuutidega moodustavad pikki substantiivifraase, mis raskendavad tekstist arusaamist. Keerukust lisab fraaside ühendamine või mitme pika substantiivifraasi kasutamine ühes lauses. Näiteks jääb genitiivatribuutide rohkuse tõttu näitelausest (63) ebaselgeks, mis mida laiendab. Näites (64) paikneb aga substantiivifraasi põhi predikaadist kaugel, mistõttu on mõtet raske jälgida.

(63) (Töövõtja kohustub:) tagama, et Ehitustööde teostamisega ei rikuta Ehitise ning seoses Ehitustööde tegemisega Töövõtja valdusse antud, Ehitise asukoha maaüksuse ning seda ümbritseva maaala ja teede heakorda ja ohutust ümbruskonnale

(64) Töövõtja kohustub tegema Tatra-Otepää-Sangaste mnt Otepää linnas/vallas asuval lõigul Hurda tn teerist - Alajaama elamurajoon kergliiklustee rajamisel välisvalgustuse rekonstrueerimistööd. 


\section{Kokkuvõte}

Lepingute lausestruktuuri analüüsi kaudu paljastuvad lepingu kui tekstiliigi üld- ja erijooned. Analüüs näitab, et töövõtu- ja käsunduslepingute pindstruktuuri laused sisaldavad ohtralt mitmesuguseid sisestatud tarindeid. Puhtkvalitatiivselt ületab nende hulk pea-, kõrval- ja kiillausete oma ligi neli korda, kuid peale hulga tuleks žanritunnustena võtta arvesse ka nende tekstifunktsioone.

Lepingute olemuslik eesmärk on määrata kindlaks poolte õigused ja kohustused. Deontilist modaalsust - kohustatust ja lubatust - annavad kõige ilmekamalt edasi $m a$ - ja $d a$-infinitiivi tarindid mitmesuguste substantiivide ja verbidega, seejuures on sõnadel kohustuma ja õigus täita põhiroll. Niisamuti on lepingute lausestruktuuri žanrispetsiifiline omadus kõikvõimalike täpsustavate tingimuste esitamine, tegevuste ja võimaluste kitsendamine. Piiranguid võimaldavad seada, tingimusi täpsustada ja tekstisiseseid viiteid lisada partitsiiptarindid (peamiselt tudja $v$-partitsiibid), kuid ka adverbialisatsioonid ja predikaadita tarindid on lepingute täpsuse ja konkreetsuse teenistuses. Seevastu nominalisatsioonid täidavad lepingutes muud funktsiooni: nende abil nimetatakse tegevusi terminilaadselt (vahel liialdatult). Nominaalstiili toetab ka lepingule kui žanrile omane staatiline, st kirjeldav ja analüüsiv väljendusviis (nimetamine ja defineerimine, seostele osutamine).

Sisestatud tarindite rohkus, kuid ka nende funktsioonid muudavad lepingukeele tahes-tahtmata keerukaks, mis omakorda võib raskendada lepingu ühemõttelist tõlgendamist. Seetõttu tuleks suuremat tähelepanu pöörata lepingutekstide koostamisele ja ametnike koolitamisele.

\section{Viidatud kirjandus}

Argus, Reili 2005. Kui sõna ei tähenda, vaid ainult teeb. - Õpetajate Leht, 25. nov, nr 42.

Askehave, Inger; Swales, John 2001. Genre identification and communicative purpose: A problem and possible solution. - Applied Linguistics, 22 (2), 195-212. http://dx.doi. org/10.1093/applin/22.2.195

Bhatia, Vijai Kumar 1993. Analysing Genre: Language Use in Professional Settings. New York: Longman.

Fairclough, Norman 2003. Analysing Discourse: Textual Analysis for Social Research. London, New York: Routledge.

Kasik, Reet 2002. Uudiste süntaks. - Renate Pajusalu, Tiit Hennoste (toim.). Tähendusepüüdja. Pühendusteos professor Haldur Õimu 60. sünnipäevaks. Tartu: Tartu Ülikooli Kirjastus.

Kasik, Reet 2006. Nominaliseeritud protsessi agent meediauudistes. - Emakeele Seltsi aastaraamat, 51 (2005), 21-37.

Kasik, Reet 2008. Infojaotus uudistekstides: partitsiiptarindid. - Emakeele Seltsi aastaraamat, 53 (2007), 48-63.

Mandra, Katrin 2007. Deontiline modaalsus eri tekstiliikides. Magistritöö. Tartu: Tartu Ülikool. http://hdl.handle.net/10062/2866 (03.03.2013).

Penjam, Pille 2008. Eesti kirjakeele $d a$ - ja $m a$-infinitiiviga konstruktsioonid. Dissertationes philologiae estonicae Universitatis Tartuensis 23. Tartu: Tartu Ülikooli Kirjastus.

Reinsalu, Riina 2011. Leping tekstiliigina: žanristruktuur. - Eesti Rakenduslingvistika Ühingu aastaraamat, 7, 215-229. http://dx.doi.org/10.5128/ERYa7.13

Reinsalu, Riina 2012. Lepingute lausestruktuur. - Emakeele Seltsi aastaraamat, 57 (2011), 218-234. http://dx.doi.org/10.3176/esa57.10 
Swales, John 1990. Genre Analysis: English in Academic and Research Settings. Cambridge: Cambridge University Press.

Zhu, Yunxia 2000. Building knowledge structures in teaching cross-cultural sales genres. - Business Communication Quarterly, 63 (4), 49-68. http://dx.doi. org/10.1177/108056990006300405

Uuspõld, Ellen 2001. des- ja mata-vormide kaassõnastumine ja eesti komareeglid. - Reet Kasik (Toim.). Keele kannul. Pühendusteos Mati Erelti 6o. sünnipäevaks 12. märtsil 2001. Tartu Ülikooli eesti keele õppetooli toimetised 17. Tartu: 306-321.

\section{Võrgumaterjalid}

Otepää vallavalitsuse dokumendiregister. http://avalik.amphora.ee/OTEPAA/documents. aspx?org=66\&unit=-1\&fid=2 (24.02.2013).

Riina Reinsalu põhilised tegevus- ja uurimisvaldkonnad on terminoloogia, õigus- ja halduskeel, tekstianalüüs.

riinareinsalu@gmail.com 


\title{
INSERTED CONSTRUCTIONS AS THE TEXT FORMATION METHOD OF CONTRACTS
}

\author{
Riina Reinsalu
}

Concerning contracts as legal texts, besides accurate content, technical accuracy, which appears in the proper structure of the text, good syntax, precise word choice and neutral style, is also expected. However, the reality is somewhat different lower-level legal and administrative texts that have not been edited tend to be syntactically more complicated than, for instance, legislative texts. Language analysis reveals that although the sentence structure of contracts is rather simple, the comprehension of a text is inhibited by several inserted constructions: non-finite clauses, participle constructions, nominalisations, adverbialisations and constructions without predicates.

Although the abundance of the inserted constructions is one of the textual characteristics of contracts, the functions that these types of constructions fulfil from the point of view of text formation have to be taken into account. The constructions of $m a$ - and $d a$-infinitive vividly pass on the essence of contracts - deontic modality - obligation and permission is expressed by different nouns and verbs, especially frequently by kohustuma and õigus. Moreover, genre-specific structural characteristics of contractual sentences set out various specifications of conditions, restriction of actions and options. With participle constructions limits are set, conditions specified and intratextual references added. Also, the adverbialisations and constructions without predicates are at the service of the accuracy and concreteness of the contracts. However, nominalisations perform a different kind of function in contracts - they pass the actions on in the same way as terms. This is supported by the genre-specific static language of a contract - that is to say, descriptive and analytical (naming and defining, referring to connections).

Both the abundance of inserted constructions and their functions make contractual language unavoidably complicated, which in turn may impede the unambiguous interpretation of a contract. Therefore, more attention should be paid to the compilation of contractual texts and the training of officials.

Keywords: genre, genre analysis, legal language, Estonian 